\title{
THE ISOLATION OF RED YEAST-LIKE FUNGI IN A DIAGNOSTIC LABORATORY
}

\author{
A. E. Jennings AND J. E. BennetT \\ Department of Clinical Pathology, Clinical Center, and Institute of Allergy and \\ Infectious Diseases, National Institutes of Health, Bethesda, Maryland 20014, USA
}

RED yeast-like fungi, usually of the genus Rhodotorula, comprise about 2-6 per cent. of yeasts isolated in clinical specimens (Mackenzie, 1961; Stenderup and Pedersen, 1962). In routine hospital laboratories such isolates usually have not been identified beyond the genus level; nor has care always been taken to separate Rhodotorula spp. from similar species of Cryptococcus or Sporobolomyces. This practice has arisen partly because species of Rhodotorula rarely cause disease in man and partly because of the lack of general agreement as to how strains of Rhodotorula should be classified.

The increasing number of infections in our hospital due to micro-organisms of low virulence, as well as the known ability of Rhodotorula spp. to cause infection (Louria, Greenberg and Molander, 1960; Shelburne and Carey, 1962; Louria et al., 1967; Leeber and Sher, 1969) prompted our decision to attempt identification of all red yeast-like fungi isolated from clinical specimens. A recently published scheme for the identification of Rhodotorula and Sporobolomyces was used (Phaff, 1970; Phaff and Ahearn, 1970). This scheme appears in the new edition of an authoritative text and may perhaps achieve general agreement as a means of identification. The scheme is straightforward and easy to use; with its aid, all 58 red yeast-like fungi isolated during a 29-mth period of investigation could be identified. Our experience suggests that the scheme should also prove useful in other clinical laboratories.

\section{MATERIALS AND METHODS}

Clinical specimens. Over the period from May 1968 to the end of September 1970, all red yeast-like fungi from clinical specimens were identified. Techniques for liquefaction of sputum, selection of media and separation of yeast into genera have been described previously (Jennings, Bennett and Young, 1968). The only modification of approach was that inositol utilisation was substituted for starch production in separating Cryptococcus from Rhodotorula (Phaff and Spencer, 1969).

Speciation of the genus Rhodotorula was done according to the scheme of Phaff and Ahearn (1970). Substrate utilisation was detected by the use of auxanograms (Jennings et al.). Plates were read after $48 \mathrm{hr}$ and again after 7 days' incubation at $28^{\circ} \mathrm{C}$. Ability to grow in the absence of vitamins was tested in broth (Difco Vitamin-free Yeast Base). After incubation at $28^{\circ} \mathrm{C}$ for $1 \mathrm{wk}$, the broth was subcultured into the same medium and observed for another week. The single isolate of $S$. salmonicolor was identified by the criteria of Phaff (1970). Ballistospore production was assessed by the technique of Carmo-Sousa and Phaff (1962). Tests were also made for two characteristics common to the pathogen C. neoformans: viz., growth at $37^{\circ} \mathrm{C}$ and pathogenicity for mice (Jennings et al.).

Received 8 Nov. 1971; accepted 20 Dec. 1971.

J. MED. MICROBIOL.-VOL. 5 (1972) 


\section{RESULTS}

During the 29-mth period of study, 8062 routine specimens from patients were cultured for fungi; Rhodotorula spp. were isolated from 57 ( 0.71 per cent.) and $S$. salmonicolor from a single specimen. There was no difficulty in allotting any of the strains isolated to one or other of the species listed in the taxonomic scheme used. The commonest source of Rhodotorula spp. was faeces, 2.6 per cent. of samples containing these fungi. The identity and source of the isolates is given in the table. Although the organisms were generally considered

TABLE

Number, identity and source of members of the genus Rhodotorula isolated from 8062 clinical specimens

\begin{tabular}{|c|c|c|c|c|c|c|c|}
\hline \multirow{2}{*}{ Source } & \multirow{2}{*}{$\begin{array}{l}\text { Number } \\
\text { of specimens } \\
\text { examined }\end{array}$} & \multirow{2}{*}{$\begin{array}{l}\text { Number } \\
\text { (and } \\
\text { percentage) } \\
\text { yielding } \\
\text { Rhodotorula } \\
\text { sp. }\end{array}$} & \multicolumn{5}{|c|}{ Number of isolations of $R$. } \\
\hline & & & aurantiaca & $\begin{array}{l}\text { glutinis } \\
\text { var. } \\
\text { glutinis }\end{array}$ & $\begin{array}{c}\text { minuta } \\
\text { var. } \\
\text { texensis }\end{array}$ & rubra & pilimanae \\
\hline $\begin{array}{l}\text { Urine } \\
\text { Stool } \\
\text { Blood and bone } \\
\text { marrow }\end{array}$ & $\begin{array}{l}1727 \\
1193 \\
2111\end{array}$ & $\begin{array}{l}13(0.75) \\
31(2.6) \\
2(0.094)\end{array}$ & $\begin{array}{l}1 \\
0 \\
1\end{array}$ & $\begin{array}{l}1 \\
0 \\
0\end{array}$ & $\begin{array}{l}3 \\
3 \\
0\end{array}$ & $\begin{array}{r}8 \\
27 \\
1\end{array}$ & $\begin{array}{l}0 \\
1 \\
0\end{array}$ \\
\hline $\begin{array}{l}\text { "Respiratory "* } \\
\text { Miscellaneous } \dagger\end{array}$ & $\begin{array}{r}883 \\
2148\end{array}$ & $\begin{array}{l}6(0.68) \\
5(0.23)\end{array}$ & $\begin{array}{l}0 \\
1\end{array}$ & $\begin{array}{l}0 \\
0\end{array}$ & $\begin{array}{l}1 \\
0\end{array}$ & $\begin{array}{l}5 \\
4\end{array}$ & $\begin{array}{l}0 \\
0\end{array}$ \\
\hline
\end{tabular}

* Sputum, bronchial washing, saliva, tracheal aspirate.

$\dagger$ Skin, throat, wound, perineum, liver.

to be commensals, there were five patients in whom the possibility of infection was considered. In addition to the two isolations of Rhodotorula from blood, $S$. salmonicolor was isolated from a specimen of cerebrospinal fluid and $R$. rubra from a liver biopsy specimen from one patient and from a wound in another. In all five cases, the diagnosis of a mycosis was eventually discarded and no antifungal therapy was given.

The presence of these fungi on or in the human body raised the question whether or not such organisms can multiply at body temperature. Definite growth at $37^{\circ} \mathrm{C}$ on Sabouraud agar was noted with one isolate of $R$. aurantiaca, six of $R$. minuta var. texensis and 27 of $R$. rubra. Two of the 57 clinical isolates reacted positively in the test of neurotropism and pathogenicity generally used in the identification of $C$. neoformans. Although none of the 57 pairs of mice inoculated with the isolates died or appeared ill during the $2 \mathrm{wk}$ after intravenous inoculation, one mouse each in two different pairs had positive brain cultures at the end of this period. Both mice had been inoculated with R. rubra.

\section{DISCUSSION}

The diversity of findings reported in published work in this field renders it difficult to say how our results compare with those of others. The total 
frequency of red yeast-like fungi we observed was 0.7 per cent., compared with 1.6 per cent. in a very similar series of specimens (Mackenzie, 1961). A low frequency has been reported in stool (0.26 per cent.; Windisch and Staib, 1955) and in the normal mouth ( 0.9 per cent.; Seebacher et al., 1971), whereas a much higher frequency has been noted in cultures from skin (Cramer and Koch, 1963; Sonck and Somersalo, 1963; Seebacher et al.) and bile (Staib, 1958).

Most of the red strains of yeast-like fungi isolated were $R$. rubra. This agrees with the majority of published accounts (Huxley and Hurd, 1956; Staib; Mackenzie; Seebacher et al.). Although such isolates were usually referred to in publications as $R$. mucilaginosa, this species is no longer considered distinct from $R$. rubra (Phaff and Ahearn, 1970). The occurrence of $R$. aurantiaca, $R$. glutinis and $R$. minuta in clinical specimens has been noted previously (Staib) though such isolations have been infrequent. The absence of previous reports of $R$. pilimanae in clinical specimens probably reflects the disordered state of the taxonomy of this genus and in particular the absence of this specific name in the taxonomic scheme of Lodder and Kreger-van Rij (1952). S. salmonicolor has rarely been isolated from man, the only instance known to us being a report of four isolations from normal skin (Huxley and Hurd). The reported occurrence of this species in air (Menna, 1954; Huxley and Hurd) and its isolation from air in our own institution suggests that its occurrence by chance in a clinical specimen may be expected.

\section{SUMMARY}

A recently published scheme of investigation was used to identify all isolates of red yeast-like fungi from clinical specimens over a 29 -mth period. In 8062 specimens we found 45 strains of Rhodotorula rubra, seven of $R$. minuta var. texensis, three of $R$. aurantiaca, one of $R$. glutinis var. glutinis, one of $R$. pilimanae and one of Sporobolomyces salmonicolor. The commonest single source of these fungi was stool, of which 2.6 per cent. of specimens yielded Rhodotorula spp. None of the strains isolated appeared to be the cause of an infection. The routine identification of red yeast-like fungi could be made without difficulty, and techniques employed are recommended to other hospital laboratories wishing to provide this service.

\section{REFERENCES}

Carmo-Sousa, L. Do., AND Phaff, H. J. 1962. An improved method for the detection of spore discharge in the Sporobolomycetaceae. J. Bact., 83, 434.

Cramer, H. J., AND Koch, H. A. 1963. Über die Bedeutung der Rhodotorula-Hefen als Krankheitserreger in der Dermatologie. Derm. Wschr., 147, 563.

HuXLeY, M. JOAN, AND HuRd, R. C. 1956. Pink yeasts isolated from human skin surfaces. J. Bact., 71, 492.

Jennings, A., BenNett, J. E., AND Young, V. 1968. Identification of Cryptococcus neoformans in a routine clinical laboratory. Mycopathologia, 35, 256.

LEEBER, D. A., AND SCHER, I. 1969. Rhodotorula fungemia presenting as "endotoxic" shock. Archs Intern. Med., 123, 78.

Lodder, JACOMINA, AND KREGer-VAN RiJ, N. J. W. 1952. The yeasts; a taxonomic study, Amsterdam, p. 645. 
Louria, D. B., Blevins, A., Armstrong, D., Burdick, R., and Lieberman, P. 1967. Fungemia caused by "nonpathogenic" yeasts. Archs Intern. Med., 119, 247.

Louria, D. B., Greenberg, S. M., AND Molander, D. W. 1960. Fungemia caused by certain non-pathogenic strains of the family Cryptococcaceae. New Engl. J. Med., $263,1281$.

MACKENZIE, D. W. R. 1961. Yeasts from human sources. Sabouraudia, 1, 8.

MenNa, Margaret E. DI 1954. Non-pathogenic yeasts of the human skin and alimentary tract: a comparative survey. J. Path. Bact., 68, 89 .

Phaff, H. J. 1970. Sporobolomyces. In The yeasts; a taxonomic study, 2nd ed., edited by J. Lodder, Amsterdam, p. 831.

Phaff, H. J., AND Ahearn, D. G. 1970. Genus Rhodotorula Harrison. In The yeasts; a taxonomic study, 2nd ed., edited by J. Lodder, Amsterdam, p. 1187.

Phaff, H. J., AND SPENCER, J. F. T. 1969. Improved parameters in the separation of species in the genera Rhodotorula and Cryptococcus. In Proc. 2nd Symp. on Yeasts, Bratislava, 1966, edited by A. Kochová-Krátochvilová, p. 59.

SeEbacher, C., Hübner, U., AND Blaschke-Hellmessen, R. 1971. Vergleichende Untersuchungen zum Vorkommen von Sprosspilzen auf gesunder und krankhaft veränderter Haut. I Mitteilung: Das Vorkommen von Sprosspilzen auf gesunder und kranker Haut. Mykosen, 14, 371.

ShelbuRNe, P. F., AND CAREx, R. J. 1962. Rhodotorula fungemia complicating staphylococcal endocarditis. J. Amer. Med. Assoc., 180, 38.

SoNCK, C. E., AND Somersalo, O. 1963. The yeast flora of the anogenital region in diabetic girls. Archs Derm., 88, 846.

StaIB, F. 1958. Rhodotorula in der Galle des Menschen. Zentbl. Bakt. ParasitKde, I Abt. Orig., 172, 142.

Stenderup, A., AND Pedersen, G. T. 1962. Yeasts of human origin. Acta. path microbiol. scand., 54, 462.

Windisch, S., AND Staib, F. 1955. Vorkommen von Hefen im Darmtrakt Kranker. Zentbl. Bakt. ParasitKde., I Abt. Orig., 164, 493. 